\title{
Beyond Uncertainty: The Long Haul of COVID-19 for Older Adults
}

\author{
Eva Kahana, PhD, Editor in Chief
}

I $t$ has been a long year since we originally posted a call for papers for the Journal of Elder Policy (JEP) related to the COVID-19 pandemic. As the papers accepted are now in print, the world is still shell shocked in the aftermath of losses and the future of uncertainty. Many of us lost family, friends, neighbors, and coworkers, and all of us lost our innocence about the predictability of our daily life and future. Older adults have been one of the most severely affected and threatened groups by the pandemic. Nevertheless, it notable that this age group does not consistently express greater worry about the pandemic than do their younger counterparts (Barber \& Kim, 2021).

Large segments of the world's older population remain unprotected from COVID-19 in countries where vaccines are hard to come by. Even in the U.S., where vaccines are readily available, there are vast differences among states in terms of vaccine hesitancy, resulting in many Southern states remaining unvaccinated. In the absence of a federal mandate, uneven vaccination rates are likely to persist along with an uneven application of protective measures (Sallam, 2021). As of September 2021, only one vaccine has received full approval from the United States Food and Drug Administration (FDA), thereby limiting more effective measures for persuading the hesitant.

This special issue of the Journal of Elder Policy on COVID-19 is being published about a year and a half after the onset of the global pandemic. Prior to this crisis, very few of us would have believed that a virus could upend the lives of the world's population and persist for such a long period. The world experienced pandemics before: Ebola, swine flu, and SARS, but they were not the same magnitude as COVID-19.

COVID-19 has resulted in unprecedented policy challenges. Experts in public health have had a difficult time providing consistent and effective guidelines for coping with challenges faced. Even as vaccines have proved to be successful in diminishing rates of infection, hospitalization, and mortality, there has been considerable political controversy regarding the best and safest ways to return to more normal lifestyles.

The case of the COVID-19 pandemic provides an exemplar of the intertwining between public policy and public attitudes. Trust in government was undermined during the period of the pandemic (Han et al., 2020). This lack of trust also coincides with the lack of individuals trusting one another. This problem was 
exemplified in the reaction to the CDC recommendation, during the spring of 2021, for eliminating the mask mandates. The question arose: Can vaccinated individuals assume that all of those no longer wearing masks have indeed been vaccinated?

Both because of the severe impact of COVID-19 and the ambiguity regarding the best ways to fight it, public policy has become polarized and the subject of major political disagreements (Alcott et al., 2020). As we begin fall of 2021, we hope to be seeing the light at the end of the tunnel of this terrible pandemic, but uncertainties abound. Masks have become a symbol of caution on the one hand and of enforced limitations on the other. The CDC has made contradictory pronouncements, and the public finds it easy to blame absence of leadership for the lack of clarity regarding prudent actions to follow (Latkin et al., 2020).

In this editorial, I aim to discuss relevance and contributions of the featured articles and acknowledge methodological limitations of empirical studies due to the pandemic. Prior to focusing on the articles published in this issue, I will briefly share my own lived experience during this period that can help contextualize the personal impact of the pandemic on older people.

\section{My Lived Experience Coping with the COVID-19 Pandemic}

B eing 80 years old, and now a widow, living alone, I can readily understand the dilemmas and insecurities of older adults in dealing with the pandemic. I noted in previous issues of $J E P$ how my husband, Boaz, a recently retired psychology professor, and I "escaped" from our rented high-rise apartment in Florida in March of 2020 and took a risky flight home to Cleveland, Ohio. Living in a single-family home felt much safer than our prior elevator rides and proximity to neighbors. During the seven months between April and October 2020, Boaz and I did not leave our Cleveland home. We shifted to telehealth visits for our health care and ordered our groceries and medications delivered by Instacart.

Our work-related and long-distance family interactions were all on Zoom. Starting in August 2020, I was teaching a combined graduate and undergraduate class on stress and coping on Zoom, with considerable help from my graduate students and my tech-savvy adult children who live nearby. In order to protect us, their elderly parents, my son and his wife started homeschooling their two children, including an autistic son. They also engaged in and advocated strict social distancing.

In my last editorial I shared my difficult experiences related to the hospitalization of my husband, Boaz, and his death on November $6^{\text {th }}$ while in a highly regarded hospital. During Boaz's hospitalization, starting in mid-October, I left my home daily to be with him, as I was the designated relative and the only one 
allowed to visit due to COVID protocols. I stopped worrying about my own safety as I felt that I needed to be with my beloved husband of 59 years. He died unexpectedly due to aspirating a large pill he was given. Our two sons were allowed to visit and be with him in his final hours.

After Boaz passed away, my surreal COVID-19 era experience continued with a Zoom funeral. Colleagues were largely absent. Friends and relatives, participating by Zoom, added to an eerie unreality of the experience. My husband's elderly sister and brother and our extended family who lived out of town could not attend Boaz's funeral. Although Boaz did not pass from COVID-19, his death was shrouded in the tragedy of the pandemic. I did the best I could to find solace in the closeness of my children. They made a major sacrifice to protect me by keeping their children out of school for most of the school year.

The new year brought rays of hope with the vaccine on the horizon. I was vaccinated in February 2021 and felt great relief. I was able to think of visiting the dentist and the podiatrist. I had been cutting my own hair during the pandemic and got used to having gray hair. About a month after being fully vaccinated I returned to the beauty shop wearing a mask.

Early this summer my vaccinated adult children and I undertook a long-distance trip to visit my younger son and five grandchildren in Philadelphia. We remained cautious about indoor dining but appreciated the return of some normalcy in our lives. My grandchildren enjoyed day camp and greatly welcomed the company of other children. We visited museums and I felt comfortable enough to take a chance on flying between Cleveland and Philadelphia.

I have been a college professor for the past 54 years and was looking forward to teaching in person this fall. I have truly missed interacting with my students, as Zoom just does not provide the same interaction as face-to-face conversations. As the summer progressed, we learned about the advance of the new Delta variant of the COVID-19 virus that can lead to breakthrough infections for vaccinated individuals. I became more concerned about in-person teaching even with the good news that all returning students must be vaccinated. Indeed, the latest University directives call for both students and professors to wear masks in class. Given that at age $80 \mathrm{I}$ am hard of hearing, a further worry now relates to my ability to understand comments and questions of my students who will be wearing masks (SheikAli et al., 2021). Due to these concerns, I requested to return to online teaching as a disability accommodation.

Although I do go out shopping and visit my children, I am still hesitant to have visitors and to eat out despite being vaccinated. As preparations for school intensify, we face further uncertainties of the new variants. This puts the fear of COVID-19 back at center stage. One of the major hardships for me is the inability to plan ahead. I had multiple abstracts that were accepted for presentation at 
the Gerontological Society of America (GSA) meetings in Phoenix, Arizona, in November, but I have been unsure about the safety of travel and face-to-face interactions. Recently GSA announced that the meeting would be switched to a virtual format. I realize that unpredictability is part of the reality of reaching old age. This may be a reason for the findings mentioned earlier that older people do not worry more than the young about the pandemic.

At the same time, the uncertainties of the pandemic still linger in my life. Last week, the UPS driver delivered the boxes that I had sent back from our trip to Philadelphia. When I noticed that the driver who was at my door was not wearing a mask, I quickly retreated to my hallway and experienced a fear I had been used to prior to vaccination.

\section{Methodological Limitations of Studies Focused on COVID-19 and Older Adults}

There have been numerous studies published over the past year, addressing the unique challenges of COVID-19 for older people. The present issue of

L JEP adds national and international contributions to better understand this important topic. In evaluating the quality of research on aging and COVID-19, we must acknowledge limitations of the current literature for offering a broad and deep understanding of the impact of the COVID-19 pandemic on lives of older adults, those of their families and caregivers and their health care providers. The problem lies in the many restrictions both researchers and their subjects have been living and operating under. Due to the ongoing threat of the pandemic, we cannot yet apply conventional methodological expectations to research on the impact of the pandemic.

Unlike traditional social science research that is based on representative samples and typically collects data through surveys or interviews administered in person, most of the current research available related to COVID-19 does not meet these standards. After the start of the pandemic, investigators lacked the usual opportunities to apply for peer reviewed funding. Nor did most investigators have the facilities and supports needed to craft first rate proposals. During lockdowns, older adults could not be interviewed in person. Pilot data was thus difficult to obtain by investigators working from home. Data from older adults could mostly be collected online or by phone.

Data for most of the COVID pandemic studies were collected during the first half of 2020. As mentioned above, in an effort to quickly collect relevant data, scholars relied on internet-based surveys (Barber \& Kim, 2021). Such surveys include an overrepresentation of educated respondents who had access to computers and the Internet and who are technologically literate. Minorities were generally underrepresented in such samples. Furthermore, older adults living in long-term 
care facilities, who were among the first major victims of the Pandemic were seldom included in research on COVID-19. These older adults lived under strict lockdowns. Their families were not permitted to visit and thus could not offer firsthand, personal testimonials about the lived experiences of this highly vulnerable and victimized group. Those elders who contracted COVID-19 in institutional facilities suffered high mortality rates. Just 2.1 million people, accounting for $0.62 \%$ of the U.S. population, reside in a nursing home or assisted living facilities. Yet as of May 22, 2020, this population constituted $42 \%$ of all COVID-19 deaths (Girvan, 2020).

Before summarizing contributions of studies included in this issue of JEP, I want to offer a few insights from the larger literature related to older adults and COVID-19. The challenges experienced by older people during the initial months of the pandemic were explored by Heid and colleagues (2021). The most frequently noted problems among their sample $(N=1272)$ related to constraints on social interactions during the pandemic. A study mixed methods study $(N=825)$ by Whitehead and Torossian (2021) echoed this finding, noting that $42 \%$ of older respondents reported constrained social interactions and 30.9\% reported activity restriction. Again, these authors found the most frequent stressors to be confinement and loneliness. However, sources of joy included family/friend relationships, digital social interactions, and hobbies. Predictors of poor psychological wellbeing during the pandemic included concern for the wellbeing of others, fears of an uncertain future, and fears of contracting the virus.

The larger literature on COVID-19 and aging also focuses on caregiving. The complex demands of caregiving to older adults during the pandemic have led to anxiety, depression, and other mental health problems among caregivers (Beach et al., 2021). The presence of multiple caregivers was often found to result in family conflict (Xu, Liu, \& Beach, 2021). With regard to policy implications of COVID-19, one of the most important lessons involves the rise of ageism (Ehni $\&$ Wahl, 2020). The adverse impact of COVID-19 on the health and survival of elderly patients has underscored vulnerability and frailty in late life, and has resulted in ageism that devalues older individuals. Because older adults were at risk for adverse outcomes related to COVID-19, they were not always considered as high priority for interventions and in some environments, they were not deemed worthy of saving (Ehni \& Wahl, 2020). Further reflecting on pervasive ageism, the United States has formally adopted the Ventilator Allocation Guidelines whereby "age may be considered as a tie-breaking criterion in limited circumstances" (Zucker, Adler, \& Berens, 2015).

As a counterpoint to arguments about the negative impact of increased ageism during the COVID pandemic, there is also some evidence of benefits derived by older adults from Federal and State based programs and entitlements that aid elders. Young and colleagues (2020) provide a list of new policies initiated in response to COVID-19 that can improve health care and quality of life of older 
adults. Some of these programs are short-term but have the potential to be extended if they prove to yield evidence warranting their long-term implementation.

\section{Connecting to Our Current COVID-19 Issue of JEP}

7 he articles published in this issue of JEP are largely responses to our call for papers. However, we also included two invited articles by physicians,

1 Dr. Heidi Gullet and Dr. Nathan Stall and colleagues, who each provided important accounts of health care providers' perspectives on the pandemic in the U.S. and in Canada, respectively. We also include cross-national perspectives from Romania in the paper contributed by Drs. Ivan and Cutler. Our papers reflect interdisciplinary perspectives and include medical, legal, nutrition, sociological, and historical approaches.

1. Equity for Older Adults and Those in Congregate Sites: Lessons from the First Year of a Local Public Health COVID-19 Response, by Heidi Gullett, MD, MPH, offers a medical and public health focus and walks the reader through her firsthand experience of serving as the Commander of the Cuyahoga County, Ohio Board of Health (CCBH) COVID-19 response team. Gullet presents details of what worked well, and lessons she and her multi-discipline team learned through this pandemic. She places particular emphasis on the impact of the pandemic on the vulnerable (e.g., older adults, the disabled, those in congregate settings, racial minorities, and individuals facing socioeconomic disadvantage) and describes how the response team attempted to mitigate COVID-19 outbreaks among these groups. Some of the efforts included a physician hotline for those without a physician, testing, support systems and vaccination efforts for marginalized groups, and building trust within the community. Lastly, Gullet provides policy recommendations which focus on strengthening public health infrastructure to prevent and/or lesson future health crises.

2. COVID-19 and Ontario's Long-Term Care Homes, by Nathan Stall, MD \& Collaborators, undertakes an extensive examination of risk factors that contributed to high incidence of COVID-19 infections in long term care facilities in Ontario, Canada. Indeed, as of July 2021, 43\% of Ontario's COVID-19 deaths were comprised of LTC residents. Analyses revealed that the risk of COVID-19 outbreaks in LTC homes was strongly associated with the rate of infection in the communities surrounding them, profit status of LTC home, and crowding. The authors also examine whether public health interventions had any impact on mitigating this risk and suggested other measures that may be effective moving forward. These measures include improving working conditions for staff, restricting employees to only working in one LTC type setting within a 14-day period, further reducing crowding, prioritizing testing, guaranteeing paid sick time for employees, improv- 
ing infection prevention, improving strategies for vaccine acceptance, and continuing the rapid collection and access to data on COVID-19 and LTC homes.

\section{Racial Differences in Self-Appraisal, Religious Coping, and Psychological} Well-being in later Life during the COVID-19 Pandemic by Timothy Goler, PhD, Tirth Bhatta, PhD, Nirmala Lekhak, PhD, and Neema Langa, MA, moves the conversation from mitigation efforts to a survey of coping resources and strategies of older persons that impacted mental health. Using a stress and coping framework, they examined racial differences in well-being of older adults during the COVID-19 pandemic. Their online survey $(\mathrm{N}=1764)$ specifically looked at how religious coping, subjective religiosity, emotional support, and self-appraisal of the pandemic shaped racial differences in anxiety and depression. Their findings revealed that Black study participants showed greater concerns about the pandemic than their white counterparts, but had fewer depressive symptoms and anxiety. Further analysis indicated that subjective religiosity, religious coping, and emotional support appeared to buffer stress for black participants. The study suggested that emotional support (for both blacks and whites) independently influences psychological well-being of the participants.

\section{Older Adults and the Digital Divide in Romania: Implications for the} Covid-19 Pandemic represents a collaboration between a Romanian communication scholar, Loredana Ivan, PhD, and a U.S.-based Sociologist, Stephen J. Cutler PhD. They explored the role of the digital divide among older adults and its implication for the COVID-19 pandemic in Romania. Since many in-person activities were moved to online platforms during the pandemic, older adults who did not have access to the Internet or who were not savvy users risked vulnerabilities. Factors that contribute to the digital divide include the cost of computers and Internet. In Eastern Europe, many younger persons leave to work abroad, and their aging relatives are left in the villages with no means of communication with their children. These older adults are motivated to learn technology but do not have the resources to purchase the needed devices. Although the data for this study was collected prior to the pandemic, Ivan and Cutler raise important points about Internet use among older adults relevant to the pandemic. Those older adults with access and skills likely found opportunities to learn new digital skills, while non-users may have faced social exclusion. They continued relying on phone calls to friends and families and meeting someone in person when facing illnesses.

\section{Differential Treatment of Older Workers Due to COVID-19 Accommoda-} tions: Potential Issues of Ageism and Age Discrimination by psychologist Lisa Hollis-Sawyer, $\mathrm{PhD}$, focuses on the challenges faced by older workers during the pandemic. The author notes that the COVID-19 pandemic shifted the environment for workers in the United States. Many were laid off or had to adapt to online platforms. Prior to the pandemic, workplace discrimination and ageism were 
already significant problems for older workers. Hollis-Sawyer examines the strain that older workers faced in relation to the pandemic by studying 2020 employment trends. Her work reveals negative impacts and wear and tear effects on older workers including involuntary early retirement, workplace discrimination based on stereotypes of technology use and perceived health vulnerability, and intergenerational tensions. Hollis-Sawyer concludes her article by suggesting ways that employers can create age-friendly work environments. Suggested strategies are: 1) reducing ageism, 2) training staff to avoid stereotyping, 3) judge workers case-bycase, and 4) training staff on aging issues.

6. The Return of Typhoid Mary? Immigrant Workers in Nursing Homes by professors of Law, Shefali Milczarek-Desai, JD, MA and Tara Sklar, JD, MPH, focuses on problems in staffing in nursing homes. Thousands of COVID-19 infections in long-term care facilities could be traced back to the nursing aides who cared for residents. The authors explore the underlying cause of high COVID transmission rates by looking at the relationship between historical epidemics in the U.S. and low-wage immigrant workers. They do this by presenting the story of "Typhoid Mary," who was a poor, Irish-immigrant worker labeled the most dangerous woman in America a century ago for spreading typhoid fever. The authors present the poor workplace conditions of aides that contributes to them working in several nursing homes and not having the ability to take paid sick time. The precarious nature of their job often led aides to choose between loss of income or contributing to the spread of the virus. The authors conclude their article by suggesting concrete policy recommendations, specifically enforcement of paid sick leave for low-wage immigrant workers.

7. A Stage Set for Disaster: For-Profit Nursing Homes, Federal Law, and COVID-19 by legal historian David Papke, JD, PhD, also shines a spotlight on the high rates of COVID-19 infection and deaths among nursing home residents. To explore why this disaster occurred within these settings, he takes an upstream approach, presenting historical information about the rise of for-profit nursing homes. Papke argues that the for-profit model does not provide safe and conscientious care for residents. For profit nursing homes often try to maximize profits by skimping on infection control measures and staffing. Papke points out that federal regulations often do little to punish nursing homes that are non-compliant, and regulations promoting infection control actually decreased leading up to the pandemic. The paper skillfully lays out the ways that these nursing homes valued profit over patient care, particularly during the Pandemic (e.g., accepting COVID-positive patients). Papke concludes with regulatory policy recommendations.

8. Nutrition-Related Policy Fundamentals for Supporting Older Adults in the Community during a Pandemic: Lessons from COVID-19 by nutrition and law scholars Meredith Whitmire, JD, Mary Beth Arensberg, PhD, RDN, Alexandra 
Ashbrook, JD, LL.M, and Robert Blancato, MPA, highlights the important role that nutrition plays in supporting a strong immune system. Unfortunately, many older adults are malnourished or face food insecurity, which places them at an increased risk for chronic conditions. Poorly nourished elders are at risk for contracting COVID-19 and suffering its complications. While malnutrition and food insecurity are known problem among older adults, they are often not screened during care visits. This article provides an overview of community-based, federally funded nutrition services for adults which became extremely important for seniors during the pandemic. Policy recommendations are laid out at the end of the article to ensure that older adults can access adequate nutrition, even post-pandemic. These recommendations focus on how to increase funding for community services which have been proven to help address this need.

\section{Conclusion}

7 he current issue of JEP is capturing an important glimpse into the ongoing COVID - 19 pandemic. Each article offers unique and creative perspectives 1 on older adults and the pandemic. Yet due to the rapidly changing nature of the threat, and the selective perspectives of authors, we only gain a partial overview of the impact of the pandemic and future needs of older adults.

At this point, it is clear that the pandemic will have lasting adverse effects on physical and mental health of older adults (Morrow-Howell, 2020). In particular, social isolation and loneliness are proving to cause major adverse mental health problems for older adults (Van Tilburg et al., 2020; Wu, 2020). However, both formal and informal programs have been found to be helpful in counteracting social isolation (Kahlon et al., 2021). There have also been some positive developments for elders based on increased technological skills, increased self-care, and proactivity in reducing social isolation (Morrow-Howell, 2020).

In early fall of 2021, at the time of our publication, we are learning to live with the realization that we are in the midst of a new surge, based on the highly contagious Delta variant affecting mostly unvaccinated individuals, but also causing breakthrough infections of the vaccinated. Although the FDA has now approved vaccines, there is still vaccine hesitancy by some. Older adults, who suffered disproportionally during the early waves, fortunately have a relatively high vaccination rates in the U.S. and are spared from the most severe outcomes, should they experience breakthrough infections (Teran et al., 2021). Yet it is increasingly clear that the pandemic is not yet behind us. Furthermore, we must live with the recognition that the COVID pandemic is a global, rather than a local problem. We must be cautious and yet we must also remain optimistic that the next chapter of this battle will bring some new "breakthrough." There are many challenges for policy makers to which innovative ideas can be of great value. 


\section{Más allá de la incertidumbre: el largo recorrido de COVID-19 para adultos mayores}

$\mathrm{H}$ a pasado un largo año desde que publicamos originalmente una convocatoria de artículos para el Journal of Elder Policy (JEP) relacionados con la pandemia de COVID-19. Como los documentos aceptados están ahora impresos, el mundo todavía está conmocionado por las secuelas de las pérdidas y el futuro de la incertidumbre. Muchos de nosotros perdimos familiares, amigos, vecinos y compañeros de trabajo, y todos perdimos nuestra inocencia sobre la previsibilidad de nuestra vida diaria y nuestro futuro. Los adultos mayores han sido uno de los grupos más afectados y amenazados por la pandemia. Sin embargo, es de destacar que este grupo de edad no expresa de manera consistente una mayor preocupación por la pandemia que sus contrapartes más jóvenes (Barber \& Kim, 2021).

Grandes segmentos de la población de edad avanzada del mundo permanecen desprotegidos del COVID-19 en países donde las vacunas son difíciles de conseguir. Incluso en los EE. UU., Donde las vacunas están fácilmente disponibles, existen grandes diferencias entre los estados en términos de vacilación a las vacunas, lo que hace que muchos estados del sur permanezcan sin vacunar. En ausencia de un mandato federal, es probable que persistan tasas de vacunación desiguales junto con una aplicación desigual de medidas de protección (Sallam, 2021). En septiembre de 2021, solo una vacuna ha recibido la aprobación completa de la Administración de Drogas y Alimentos de los Estados Unidos (FDA), lo que limita las medidas más efectivas para persuadir a los indecisos.

Este número especial de Journal of Elder Policy sobre COVID-19 se publica aproximadamente un año y medio después del inicio de la pandemia mundial. Antes de esta crisis, muy pocos de nosotros hubiéramos creído que un virus podría alterar la vida de la población mundial y persistir durante un período tan largo. El mundo experimentó pandemias antes: Ébola, gripe porcina y SARS, pero no fueron de la misma magnitud que COVID-19.

COVID-19 ha generado desafíos políticos sin precedentes. Los expertos en salud pública han tenido dificultades para proporcionar pautas coherentes y efectivas para hacer frente a los desafíos que enfrentan. Aun cuando las vacunas han demostrado ser exitosas para disminuir las tasas de infección, hospitalización y mortalidad, ha habido una controversia política considerable sobre las mejores y más seguras formas de volver a estilos de vida más normales.

El caso de la pandemia COVID-19 proporciona un ejemplo del entrelazamiento entre las políticas públicas y las actitudes públicas. La confianza en el gobierno se vio socavada durante el período de la pandemia (Han et al., 2020). 
Esta falta de confianza también coincide con la falta de confianza entre las personas. Este problema se ejemplificó en la reacción a la recomendación de los CDC, durante la primavera de 2021, de eliminar los mandatos de máscaras. Surgió la pregunta: ¿Pueden las personas vacunadas asumir que todas las personas que ya no usan máscaras han sido vacunadas?

Tanto por el severo impacto del COVID-19 como por la ambigüedad sobre las mejores formas de combatirlo, la política pública se ha polarizado y es objeto de importantes desacuerdos políticos (Alcott et al., 2020). Al comenzar el otoño de 2021, esperamos ver la luz al final del túnel de esta terrible pandemia, pero abundan las incertidumbres. Las máscaras se han convertido en un símbolo de precaución por un lado y de limitaciones impuestas por el otro. El CDC ha hecho pronunciamientos contradictorios, y el público encuentra fácil culpar a la ausencia de liderazgo por la falta de claridad con respecto a las acciones prudentes a seguir (Latkin et al., 2020).

En este editorial, mi objetivo es discutir la relevancia y las contribuciones de los artículos presentados y reconocer las limitaciones metodológicas de los estudios empíricos debido a la pandemia. Antes de centrarme en los artículos publicados en este número, compartiré brevemente mi propia experiencia vivida durante este período que puede ayudar a contextualizar el impacto personal de la pandemia en las personas mayores.

\section{Mi experiencia vivida lidiando con la pandemia de COVID-19}

$\mathrm{A}$ los 80 años, ahora viuda y viviendo sola, puedo comprender fácilmente los dilemas y las inseguridades de los adultos mayores al enfrentar la pandemia. Observé en números anteriores de JEP cómo mi esposo, Boaz, un profesor de psicología recientemente jubilado, y yo "escapamos" de nuestro apartamento alquilado en Florida en marzo de 2020 y tomamos un arriesgado vuelo a casa en Cleveland, Ohio. Vivir en una casa unifamiliar se sintió mucho más seguro que nuestros anteriores viajes en ascensor y la proximidad a los vecinos. Durante los siete meses entre abril y octubre de 2020, Boaz y yo no salimos de nuestra casa en Cleveland. Cambiamos a las visitas de telesalud para nuestro cuidado de la salud y pedimos nuestros comestibles y medicamentos entregados por Instacart.

Nuestras interacciones familiares a distancia y relacionadas con el trabajo estaban todas en Zoom. A partir de agosto de 2020, estaba impartiendo una clase combinada de posgrado y pregrado sobre el estrés y el afrontamiento en Zoom, con una ayuda considerable de mis estudiantes de posgrado y mis hijos adultos conocedores de la tecnología que viven cerca. Para protegernos a nosotros, sus padres ancianos, mi hijo y su esposa comenzaron a educar en el hogar a sus dos hijos, incluido un hijo autista. También se comprometieron y mantuvieron un distanciamiento social estricto. 
En mi último editorial compartí mis difíciles experiencias relacionadas con la hospitalización de mi esposo, Boaz, y su muerte el 6 de noviembre mientras estaba en un hospital de gran prestigio. Durante la hospitalización de Boaz, a partir de mediados de octubre, salí de mi casa todos los días para estar con él, ya que yo era el pariente designado y el único al que se le permitía visitar debido a los protocolos de COVID. Dejé de preocuparme por mi propia seguridad porque sentía que necesitaba estar con mi amado esposo de 59 años. Murió inesperadamente debido a la aspiración de una pastilla grande que le dieron. A nuestros dos hijos se les permitió visitarlo y estar con él en sus últimas horas.

Después de la muerte de Boaz, mi experiencia surrealista de la era del COVID-19 continuó con un funeral de Zoom. Los colegas estuvieron en gran parte ausentes. Amigos y familiares, que participaron de Zoom, se sumaron a la inquietante irrealidad de la experiencia. La hermana y el hermano mayores de mi esposo y nuestra familia extendida que vivía fuera de la ciudad no pudieron asistir al funeral de Booz. Aunque Booz no pasó de COVID-19, su muerte estuvo envuelta en la tragedia de la pandemia. Hice lo mejor que pude para encontrar consuelo en la cercanía de mis hijos. Hicieron un gran sacrificio para protegerme al mantener a sus hijos fuera de la escuela durante la mayor parte del año escolar.

El nuevo año trajo rayos de esperanza con la vacuna en el horizonte. Me vacunaron en febrero de 2021 y sentí un gran alivio. Pude pensar en visitar al dentista y al podólogo. Me había estado cortando el pelo durante la pandemia y me acostumbré a tener canas. Aproximadamente un mes después de estar completamente vacunada, regresé al salón de belleza con una máscara.

A principios de este verano, mis hijos adultos vacunados y yo hicimos un viaje de larga distancia para visitar a mi hijo menor y cinco nietos en Filadelfia. Seguimos siendo cautelosos acerca de las comidas en el interior, pero apreciamos el regreso de algo de normalidad en nuestras vidas. Mis nietos disfrutaron del campamento diurno y dieron la bienvenida a la compañía de otros niños. Visitamos museos y me sentí lo suficientemente cómodo como para arriesgarme a volar entre Cleveland y Filadelfia.

He sido profesor universitario durante los últimos 54 años y estaba ansioso por enseñar en persona este otoño. Realmente he echado de menos interactuar con mis alumnos, ya que Zoom simplemente no proporciona la misma interacción que las conversaciones cara a cara. A medida que avanzaba el verano, nos enteramos del avance de la nueva variante Delta del virus COVID-19 que puede conducir a infecciones sin precedentes en las personas vacunadas. Me preocupé más por la enseñanza en persona incluso con la buena noticia de que todos los estudiantes que regresan deben vacunarse. De hecho, las últimas directivas universitarias exigen que tanto los estudiantes como los profesores usen máscaras en clase. Dado que a los 80 años tengo problemas de audición, una preocupación adicional ahora se relaciona con mi capacidad para comprender los comentarios y 
preguntas de mis estudiantes que usarán máscaras (Sheik-Ali et al., 2021). Debido a estas preocupaciones, solicité volver a la enseñanza en línea como una adaptación para discapacitados.

Aunque salgo de compras y visito a mis hijos, todavía dudo en recibir visitas y comer fuera a pesar de estar vacunada. A medida que se intensifican los preparativos para la escuela, nos enfrentamos a más incertidumbres de las nuevas variantes. Esto vuelve a poner el miedo al COVID-19 en el centro del escenario. Una de las mayores dificultades para mí es la incapacidad de planificar el futuro. Tuve varios resúmenes que fueron aceptados para su presentación en las reuniones de la Sociedad Gerontológica de América (GSA) en Phoenix, Arizona, en noviembre, pero no estaba seguro de la seguridad de los viajes y las interacciones cara a cara. Recientemente, GSA anunció que la reunión cambiaría a un formato virtual. Me doy cuenta de que la imprevisibilidad es parte de la realidad de llegar a la vejez. Esta puede ser una razón para los hallazgos mencionados anteriormente de que las personas mayores no se preocupan más que los jóvenes por la pandemia.

Al mismo tiempo, las incertidumbres de la pandemia aún persisten en mi vida. La semana pasada, el conductor de UPS entregó las cajas que había enviado de nuestro viaje a Filadelfia. Cuando me di cuenta de que el conductor que estaba en mi puerta no llevaba una máscara, me retiré rápidamente a mi pasillo y experimenté un miedo al que estaba acostumbrado antes de la vacunación.

\section{Limitaciones metodológicas de los estudios centrados en COVID-19 y adultos mayores}

\footnotetext{
e han publicado numerosos estudios durante el año pasado, que abordan los desafíos únicos de COVID-19 para las personas mayores. El presente núme$\checkmark$ ro de JEP agrega contribuciones nacionales e internacionales para comprender mejor este importante tema. Al evaluar la calidad de la investigación sobre el envejecimiento y COVID-19, debemos reconocer las limitaciones de la literatura actual para ofrecer una comprensión amplia y profunda del impacto de la pandemia de COVID-19 en las vidas de los adultos mayores, las de sus familias y cuidadores y sus proveedores de atención médica. El problema radica en las muchas restricciones bajo las que tanto los investigadores como sus sujetos han estado viviendo y operando. Debido a la amenaza constante de la pandemia, todavía no podemos aplicar las expectativas metodológicas convencionales a la investigación sobre el impacto de la pandemia.

A diferencia de la investigación tradicional de las ciencias sociales que se basa en muestras representativas y generalmente recopila datos a través de encuestas o entrevistas administradas en persona, la mayoría de las investigaciones actuales disponibles relacionadas con COVID-19 no cumplen con estos estándares. Después del inicio de la pandemia, los investigadores carecieron de las opor-
} 
tunidades habituales para solicitar financiación revisada por pares. La mayoría de los investigadores tampoco tenían las instalaciones y los apoyos necesarios para elaborar propuestas de primer nivel. Durante los encierros, los adultos mayores no pueden ser entrevistados en persona. Por lo tanto, los investigadores que trabajaban desde casa eran difíciles de obtener datos piloto. Los datos de los adultos mayores se pueden recopilar principalmente en línea o por teléfono.

Los datos de la mayoría de los estudios sobre la pandemia de COVID se recopilaron durante la primera mitad de 2020. Como se mencionó anteriormente, en un esfuerzo por recopilar rápidamente datos relevantes, los académicos se basaron en encuestas basadas en Internet (Barber \& Kim, 2021). Tales encuestas incluyen una sobrerrepresentación de encuestados educados que tenían acceso a computadoras e Internet y que están alfabetizados en tecnología. En general, las minorías estaban subrepresentadas en esas muestras. Además, los adultos mayores que viven en centros de atención a largo plazo, que se encontraban entre las primeras víctimas importantes de la pandemia, rara vez se incluyeron en la investigación sobre COVID-19. Estos adultos mayores vivían bajo estrictos confinamientos. A sus familias no se les permitió visitar y, por lo tanto, no pudieron ofrecer testimonios personales de primera mano sobre las experiencias vividas de este grupo altamente vulnerable y victimizado. Los ancianos que contrajeron COVID-19 en instalaciones institucionales sufrieron altas tasas de mortalidad. Solo 2,1 millones de personas, que representan el 0,62\% de la población de los EE. UU., Residen en un hogar de ancianos o instalaciones de vida asistida. Sin embargo, al 22 de mayo de 2020, esta población constituía el 42\% de todas las muertes por COVID-19 (Girvan, 2020).

Antes de resumir las contribuciones de los estudios incluidos en este número de JEP, quiero ofrecer algunas ideas de la literatura más amplia relacionada con los adultos mayores y el COVID-19. Los desafíos experimentados por las personas mayores durante los primeros meses de la pandemia fueron explorados por Heid y sus colegas (2021). Los problemas observados con más frecuencia entre su muestra $(\mathrm{N}=1272)$ se relacionaron con las limitaciones en las interacciones sociales durante la pandemia. Un estudio de métodos mixtos $(\mathrm{N}=825)$ realizado por Whitehead y Torossian (2021) se hizo eco de este hallazgo, y señaló que el $42 \%$ de los encuestados mayores informaron interacciones sociales restringidas y el 30,9\% informó restricción de actividad. Nuevamente, estos autores encontraron que los factores estresantes más frecuentes eran el confinamiento y la soledad. Sin embargo, las fuentes de alegría incluyen las relaciones familiares / amigos, las interacciones sociales digitales y los pasatiempos. Los predictores de un bienestar psicológico deficiente durante la pandemia incluyeron la preocupación por el bienestar de los demás, el temor a un futuro incierto y el temor a contraer el virus.

La literatura más amplia sobre COVID-19 y el envejecimiento también se centra en la prestación de cuidados. Las complejas demandas del cuidado de los 
adultos mayores durante la pandemia han provocado ansiedad, depresión y otros problemas de salud mental entre los cuidadores (Beach et al., 2021). A menudo se descubrió que la presencia de múltiples cuidadores generaba conflictos familiares (Xu, Liu y Beach, 2021). Con respecto a las implicaciones políticas de COVID-19, una de las lecciones más importantes involucra el aumento de la discriminación por edad (Ehni \& Wahl, 2020). El impacto adverso del COVID-19 en la salud y la supervivencia de los pacientes de edad avanzada ha subrayado la vulnerabilidad y la fragilidad en la vejez y ha dado lugar a una discriminación por edad que devalúa a las personas de edad avanzada. Debido a que los adultos mayores estaban en riesgo de sufrir resultados adversos relacionados con COVID-19, no siempre se los consideró de alta prioridad para las intervenciones y, en algunos entornos, no se consideró que valieran la pena salvarlos (Ehni y Wahl, 2020). Reflexionando aún más sobre la discriminación por edad generalizada, los Estados Unidos han adoptado formalmente las Pautas de asignación de ventiladores según las cuales "la edad puede ser considerada como un criterio de desempate en circunstancias limitadas" (Zucker, Adler y Berens, 2015).

Como contrapunto a los argumentos sobre el impacto negativo del aumento de la discriminación por edad durante la pandemia de COVID, también hay alguna evidencia de los beneficios derivados de los adultos mayores de los programas y derechos federales y estatales que ayudan a los ancianos. Young y colegas (2020) proporcionan una lista de nuevas políticas iniciadas en respuesta al COVID-1919 que pueden mejorar la atención médica y la calidad de vida de los adultos mayores. Algunos de estos programas son a corto plazo, pero tienen el potencial de ampliarse si se demuestra que aportan pruebas que justifiquen su implementación a largo plazo.

\section{Conexión con nuestra edición actual de COVID-19 de JEP}

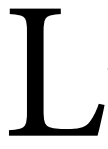

os artículos publicados en este número de JEP son en gran parte respuestas a nuestra convocatoria de trabajos. Sin embargo, también incluimos dos artículos invitados por médicos, la Dra. Heidi Gullet y el Dr. Nathan Stall y sus colegas, quienes brindaron informes importantes sobre las perspectivas de los proveedores de atención médica sobre la pandemia en los EE. UU. Y Canadá, respectivamente. También incluimos perspectivas transnacionales de Rumania en el documento aportado por los Dres. Ivan y Cutler. Nuestros artículos reflejan perspectivas interdisciplinarias e incluyen enfoques médicos, legales, nutricionales, sociológicos e históricos.

\section{Equidad para adultos mayores y personas en sitios de congregación: leccio- nes del primer año de una respuesta de salud pública local COVID-19, por Heidi Gullett, MD, MPH ofrece un enfoque médico y de salud pública y guía al lector a través de su experiencia de primera mano al servir como comandante del}


equipo de respuesta COVID-19 de la Junta de Salud de Ohio (CCBH) del condado de Cuyahoga. Gullet presenta detalles de lo que funcionó bien y lecciones que ella y su equipo multidisciplinario aprendieron a través de esta pandemia. Ella pone especial énfasis en el impacto de la pandemia en los vulnerables (por ejemplo, adultos mayores, discapacitados, aquellos en entornos congregados, minorías raciales e individuos que enfrentan desventajas socioeconómicas) y describe cómo el equipo de respuesta intentó mitigar los brotes de COVID-19 entre estos grupos. Algunos de los esfuerzos incluyeron una línea telefónica directa para médicos para quienes no tenían médico, pruebas, sistemas de apoyo y esfuerzos de vacunación para grupos marginados, y generación de confianza dentro de la comunidad. Por último, Gullet ofrece recomendaciones de políticas que se centran en el fortalecimiento de la infraestructura de salud pública para prevenir y / o aprender de futuras crisis de salud.

\section{COVID-19 y los hogares de cuidados a largo plazo en Ontario, por Nathan}

Stall, MD y colaboradores lleva a cabo un examen exhaustivo de los factores de riesgo que contribuyeron a la alta incidencia de infecciones por COVID-19 en centros de atención a largo plazo en Ontario, Canadá. De hecho, en julio de 2021, el 43\% de las muertes por COVID-19 de Ontario estaban compuestas por residentes de LTC (hogares de cuidos a largo plazo). Los análisis revelaron que el riesgo de brotes de COVID-19 en hogares LTC estaba fuertemente asociado con la tasa de infección en las comunidades que los rodean, el estado de ganancias de los hogares LTC y el hacinamiento. Los autores también examinan si las intervenciones de salud pública tuvieron algún impacto en la mitigación de este riesgo y sugirieron otras medidas que pueden ser efectivas en el futuro. Estas medidas incluyen mejorar las condiciones de trabajo para el personal, restringir a los empleados a trabajar solo en un entorno de tipo LTC dentro de un período de 14 días, reducir aún más el hacinamiento, priorizar las pruebas, garantizar el tiempo pagado por enfermedad para los empleados, mejorar la prevención de infecciones, mejorar las estrategias para la aceptación de vacunas, y continuar con la recopilación rápida y el acceso a datos sobre los hogares COVID-19 y LTC.

\section{Diferencias raciales en autoevaluación, afrontamiento religioso y bienestar psicológico en la vida posterior durante la pandemia COVID-19 por Timo- thy Goler, PhD, Tirth Bhatta, PhD, Nirmala Lekhak, PhD y Neema Langa, MA} mueve la conversación de esfuerzos de mitigación a una encuesta de recursos y estrategias de afrontamiento de las personas mayores que impactaron la salud mental. Usando un marco de estrés y afrontamiento, examinaron las diferencias raciales en el bienestar de los adultos mayores durante la pandemia de COVID-19. Su encuesta en línea $(N=1764)$ analizó específicamente cómo el afrontamiento religioso, la religiosidad subjetiva, el apoyo emocional y la autoevaluación de la pandemia moldearon las diferencias raciales en la ansiedad y la depresión. Sus hallazgos revelaron que los participantes negros del estudio mostraban mayor preocupación por la pandemia 
que sus homólogos blancos, pero tenían menos síntomas depresivos y ansiedad. Un análisis más detallado indicó que la religiosidad subjetiva, el afrontamiento religioso y el apoyo emocional parecían amortiguar el estrés de los participantes negros. El estudio sugirió que el apoyo emocional (tanto para negros como para blancos) influye de forma independiente en el bienestar psicológico de los participantes.

\section{Adultos mayores y la brecha digital en Rumania: implicaciones para la pan-} demia Covid-19 representa una colaboración entre una académica rumana en comunicación, Loredana Ivan, $\mathrm{PhD}$, y un sociólogo radicado en los EE. UU., Stephen J. Cutler PhD. Exploraron el papel de la brecha digital entre los adultos mayores y su implicación para la pandemia de COVID-19 en Rumania. Dado que muchas actividades en persona se trasladaron a plataformas en línea durante la pandemia, los adultos mayores que no tenían acceso a Internet o que no eran usuarios inteligentes se arriesgaron a sufrir vulnerabilidades. Los factores que contribuyen a la brecha digital incluyen el costo de las computadoras e Internet. En Europa del Este, muchos jóvenes se van a trabajar al extranjero y sus parientes ancianos se quedan en las aldeas sin medios de comunicación con sus hijos. Estos adultos mayores están motivados para aprender tecnología, pero no tienen los recursos para comprar los dispositivos necesarios. Aunque los datos para este estudio se recopilaron antes de la pandemia, Ivan y Cutler plantean puntos importantes sobre el uso de Internet entre los adultos mayores relacionados con la pandemia. Los adultos mayores con acceso y habilidades probablemente encontraron oportunidades para aprender nuevas habilidades digitales, mientras que los no usuarios pueden haber enfrentado la exclusión social. Continuaron confiando en las llamadas telefónicas a amigos y familiares y conociendo a alguien en persona cuando enfrentaban enfermedades.

5. Tratamiento diferencial de los trabajadores mayores debido a las adaptaciones de COVID-19: problemas potenciales de discriminación por edad y discriminación por edad por la psicóloga Lisa Hollis-Sawyer, $\mathrm{PhD}$, se centra en los desafíos que enfrentan los trabajadores mayores durante la pandemia. El autor señala que la pandemia de COVID-19 cambió el entorno para los trabajadores en los Estados Unidos. Muchos fueron despedidos o tuvieron que adaptarse a plataformas en línea. Antes de la pandemia, la discriminación y la discriminación por edad en el lugar de trabajo ya eran problemas importantes para los trabajadores mayores. Hollis-Sawyer examina la tensión que enfrentan los trabajadores mayores en relación con la pandemia al estudiar las tendencias de empleo de 2020. Su trabajo revela impactos negativos y efectos de desgaste en los trabajadores mayores, incluida la jubilación anticipada involuntaria, la discriminación en el lugar de trabajo basada en los estereotipos del uso de la tecnología y la vulnerabilidad de salud percibida, y las tensiones intergeneracionales. Hollis-Sawyer concluye su artículo sugiriendo formas en que los empleadores pueden crear entornos laborales amigables con las personas mayores. Las estrategias sugeridas son: 1) reducir la 
discriminación por edad, 2) capacitar al personal para evitar los estereotipos, 3) juzgar a los trabajadores caso por caso y 4) capacitar al personal en cuestiones de envejecimiento.

6. ¿El regreso de Typhoid Mary? Trabajadores inmigrantes en hogares de ancianos por los profesores de derecho, Shefali Milczarek-Desai, JD, MA y Tara Sklar, JD, MPH, se centra en los problemas de personal en los hogares de ancianos. Miles de infecciones por COVID-19 en centros de atención a largo plazo se remontan a los auxiliares de enfermería que cuidaban a los residentes. Los autores exploran la causa subyacente de las altas tasas de transmisión de COVID al observar la relación entre las epidemias históricas en los EE. UU. Y los trabajadores inmigrantes con bajos salarios. Lo hacen presentando la historia de "Typhoid Mary", que era una trabajadora pobre e inmigrante irlandesa etiquetada como la mujer más peligrosa de Estados Unidos hace un siglo por propagar la fiebre tifoidea. Los autores presentan las malas condiciones laborales de los auxiliares que contribuye a que trabajen en varios hogares de ancianos y no tengan la capacidad de tomar licencia por enfermedad remunerada. La naturaleza precaria de su trabajo a menudo llevó a los asistentes a elegir entre la pérdida de ingresos o contribuir a la propagación del virus. Los autores concluyen su artículo sugiriendo recomendaciones políticas concretas, específicamente la aplicación de la licencia por enfermedad pagada para los trabajadores inmigrantes con salarios bajos.

7. Un escenario preparado para un desastre: hogares de ancianos con fines de lucro, ley federal y COVID-19 por el historiador legal David Papke, JD, PhD, también destaca las altas tasas de infección y muertes por COVID-19 entre los residentes de hogares de ancianos. Para explorar por qué ocurrió este desastre en estos entornos, adopta un enfoque ascendente, presentando información histórica sobre el auge de los hogares de ancianos con fines de lucro. Papke sostiene que el modelo con fines de lucro no brinda atención segura y concienzuda a los residentes. Los hogares de ancianos con fines de lucro a menudo tratan de maximizar las ganancias escatimando en las medidas de control de infecciones y en la dotación de personal. Papke señala que las regulaciones federales a menudo hacen poco para castigar a los hogares de ancianos que no cumplen, y las regulaciones que promueven el control de infecciones en realidad disminuyeron antes de la pandemia. El documento describe hábilmente las formas en que estos asilos de ancianos valoraban las ganancias sobre la atención al paciente, particularmente durante la pandemia (por ejemplo, aceptando pacientes con COVID positivo). Papke concluye con recomendaciones de política regulatoria.

8. Fundamentos de las políticas relacionadas con la nutrición para apoyar a los adultos mayores en la comunidad durante una pandemia: lecciones de COVID-19 de los académicos de derecho y nutrición Meredith Whitmire, JD, Mary Beth Arensberg, PhD, RDN, Alexandra Ashbrook, JD, LL.M y Robert 
Blancato, MPA, destaca el importante papel que juega la nutrición en el apoyo a un sistema inmunológico fuerte. Desafortunadamente, muchos adultos mayores están desnutridos o enfrentan inseguridad alimentaria, lo que los coloca en un mayor riesgo de padecer enfermedades crónicas. Los ancianos mal alimentados corren el riesgo de contraer COVID-19 y sufrir sus complicaciones. Si bien la desnutrición y la inseguridad alimentaria son un problema conocido entre los adultos mayores, a menudo no se examinan durante las visitas de atención. Este artículo ofrece una descripción general de los servicios de nutrición comunitarios y financiados por el gobierno federal para adultos que se volvieron extremadamente importantes para las personas mayores durante la pandemia. Las recomendaciones de política se establecen al final del artículo para garantizar que los adultos mayores puedan acceder a una nutrición adecuada, incluso después de una pandemia. Estas recomendaciones se centran en cómo aumentar los fondos para los servicios comunitarios que han demostrado ayudar a abordar esta necesidad.

\section{Conclusión}

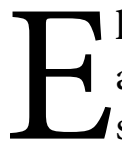

1 número actual de JEP está captando un vistazo importante a la pandemia actual de COVID -19. Cada artículo ofrece perspectivas únicas y creativas sobre los adultos mayores y la pandemia. Sin embargo, debido a la naturaleza rápidamente cambiante de la amenaza y las perspectivas selectivas de los autores, solo obtenemos una visión general parcial del impacto de la pandemia y las necesidades futuras de los adultos mayores.

En este punto, está claro que la pandemia tendrá efectos adversos duraderos en la salud física y mental de los adultos mayores (Morrow-Howell, 2020). En particular, el aislamiento social y la soledad están causando importantes problemas de salud mental adversos para los adultos mayores (Van Tilburg et al., 2020; Wu, 2020). Sin embargo, se ha descubierto que tanto los programas formales como los informales son útiles para contrarrestar el aislamiento social (Kahlon et al., 2021). También ha habido algunos avances positivos para los ancianos basados en mayores habilidades tecnológicas, mayor cuidado personal y proactividad para reducir el aislamiento social (Morrow-Howell, 2020).

A principios del otoño de 2021, en el momento de nuestra publicación, estamos aprendiendo a vivir con la conciencia de que estamos en medio de una nueva oleada, basada en la variante Delta altamente contagiosa que afecta principalmente a personas no vacunadas, pero que también causa infecciones irruptivas de los vacunados. Aunque la FDA ha aprobado ahora las vacunas, algunos todavía dudan sobre las vacunas. Los adultos mayores, que sufrieron de manera desproporcionada durante las primeras oleadas, afortunadamente tienen tasas de vacunación relativamente altas en los EE. UU. Y se libran de los resultados más graves en caso de que experimenten infecciones irruptivas (Teran et al., 2021). Sin 
embargo, es cada vez más evidente que la pandemia aún no ha terminado. Además, debemos vivir con el reconocimiento de que la pandemia de COVID es un problema global, más que local. Debemos ser cautelosos y, sin embargo, también debemos permanecer optimistas de que el próximo capítulo de esta batalla traerá un nuevo "avance". Hay muchos desafíos para los responsables de la formulación de políticas para los que las ideas innovadoras pueden ser de gran valor.

\section{不只是不确定性：长期的新冠疫情对老年人产生的影响}

距我们最初发出《老年政策期刊》（JEP）2019冠状病毒病（COVID-19） 大流行特刊文章征集已过去一年时间。已收录的文章正在刊印，同时世界 仍然因大流行造成的损失和不确定性的未来而受到弹震影响。我们中的许 多人失去了家庭、朋友、邻居和同事，并且我们都对每日生活及未来的可 预见性失去了信心。老年人一直是最受大流行影响和威胁的群体之一。尽 管如此, 值得注意的是, 老年人与年轻人相比, 前者并不持续地表达有关 大流行的、更大的担忧。

全球老年人口中, 很多人仍然未接种COVID-19疫苗, 他们生活在难以获 得疫苗的国家。即使在美国这一疫苗可用量充足的国家，各州在对疫苗持 迟疑态度一事上存在显著差异, 导致许多南部州的人民未接种疫苗。在缺 少联邦授权的情况下, 不均衡的疫苗接种率很有可能持续, 伴随保护措施 的不均衡应用（Sallam，2021）。截至2021年9月，仅有一种疫苗获得了美 国食品药品监督管理局（FDA）的全面批准，因此限制了用于说服犹豫人 士的更有效的措施。

本期《老年政策期刊》特刊聚焦于COVID-19，发行时间距离全球大流行 开始近一年半。在该危机之前，很少有人相信一场病毒能颠倒世界人民的 生活, 并在如此长的时间里持续进行。之前遭遇的大流行包括埃博拉病 毒、猪流感和非典，但它们的规模都不及COVID-19。

COVID-19已造成许多前所未有的政策挑战。公共卫生专家在 “提供持续 有效的挑战应对指南”一事上度过了艰难时刻。甚至当疫苗被证明能成功 减少感染率、住院率和死亡率时，仍然有大量政治争议探讨关于回到更正 常的生活方式的最佳且最安全的方法。

COVID-19大流行为公共政策与公共态度之间的交织（intertwining）提供 了范例。对政府的信任在大流行期间已受到破坏（Han et al., 2020）。对政 府信任的缺乏同时伴随着个体间相互信任的缺乏。人们对 2021 年春季疾控 中心提出解除戴口罩义务建议的反应则是一个例证。问题在于：已接种疫 苗的个体会认为那些不再佩戴口罩的人的确接种过疫苗吗? 
鉴于COVID-19的严重影响以及尚不清晰的抗击疫情最佳方法，公共政策 已出现极化, 成为重大政治不和的主题（Alcott et al., 2020）。2021年秋季 开始之际，我们希望在这场糟糕的大流行中看到一线希望，尽管仍然存在 许多不确定性。口罩在一方面成为了小心的象征，另一方面成为强制限制 的象征。疾控中心已发出矛盾的声明, 并且公众很容易将 “关于采取谨慎 行动一事的不清晰” 的责任归于缺乏领导力。

本篇社论中，我旨在探讨所收录文章的相关性和贡献，并承认因大流行导 致的实证研究的方法论限制。在聚焦于本期文章之前, 我将简要分享我在 此期间的经历，这能帮助将大流行对老年人产生的个人影响情境化。

\section{我在应对COVID-19大流行方面的经历}

作为一名失去丈夫的 80 岁独居老人，我很能理解老年人在应对大流行时遭 遇的困境和不安全。我在前几期JEP中提到了我的丈夫Boaz，一名近期退 休的心理学教授, 和我在 2020 年3月如何 “逃离” 我们在弗罗里达州租住 的高层公寓，冒着风险乘飞机回到俄亥俄州克利夫兰的家中。住在一户家 庭中比乘坐电梯和靠近邻居的感觉要安全得多。2020年4月至10月这7个月 中, Boaz和我都没有离开克利夫兰的家。我们转而使用远程医疗咨询并通 过杂货公司Instacart上门运送杂货和药物。

我们通过Zoom进行与工作相关的互动和远距离家庭互动。2020年8月起, 我开始在Zoom上对研究生和本科生进行混合授课, 授课内容关于压力和 应对, 我的研究生和懂技术的成年子女（他们居住在附近）给予了大量帮 助。为保护他们年迈的双亲，我们的儿子和儿媳开始对他们的子女（包括 一名自闭症男孩）进行家庭教学。他们同样参与并倡导严格的保持社交距 离。

在上一期社论中，我就Boaz住院治疗以及于2020年11月6日在一家著名医院 去世一事分享了我的困难经历。Boaz住院期间（始于2020年10月中旬）, 我每天离开家陪伴他, 因为我是指定亲人以及在COVID医疗条件下唯一能 拜访他的人。我停止担心自身安全，因为我需要和深爱59年之久的丈夫在 一起。他在被抽吸一颗大药片的过程中意外去世。我们的两个儿子被允许 在他生命最后的几个小时里陪伴他。

Boaz去世后，我的离奇COVID-19经历以一场Zoom葬礼继续进行。同事大 多数都未到场。通过Zoom参与葬礼的朋友和亲人增添了这次经历的怪异 不真实性。我丈夫的姐姐和哥哥以及居住在城外的大家庭无法参加葬礼。 尽管Boaz的去世并不是因为COVID-19，但他的离世却笼罩在大流行这一 悲剧下。我尽力从子女的关怀中获得安慰。他们为了保护我付出了巨大牺 牲一让自己的子女居家学习近一个学年。

新的一年随着疫苗的出现而带来了希望的曙光。我在2021年2月接种了疫苗 并感到放松许多。我能够考虑拜访牙医和足科医生。在这之前我一直给自 
己理发并且习惯了白发。在接种疫苗完毕一个月后, 我佩戴着口罩回到了 美容院。

今年初夏, 我和接种完毕的子女进行了一次长途旅行, 去费城拜访我的小 儿子以及他的五个孩子。我们仍然对室内进餐持谨慎态度, 但对生活恢复 部分正常一事表示欢迎。孙辈们开心地度过了白天露营, 并欢迎其他孩子 的陪伴玩要。我们参观了博物馆并且我对冒险乘飞机往返克利夫兰和费城 一事感到很安心。

作为一名大学教授，我已从事54年的工作，并且期望在今年秋季进行面对 面授课。我十分想念与学生的互动, 因为Zoom无法提供与面对面交流一 样的互动。随着夏天的进行, 我们了解了COVID-19新型变异毒株德尔塔 病毒, 它能导致疫苗接种者出现突破性感染。因此, 我对面对面教学一事 变得更为担心，尽管所有返校学生必须完成疫苗接种。的确，大学最新的 规定呼吁学生和教授都佩戴口罩上课。鉴于 80 岁的我存在听力障碍,一个 进一步的担心则有关于我是否能理解佩戴口罩上课的学生的评论和提问 (Sheik-Ali et al., 2021) 。出于这些顾虑, 我请求回到网络教学 (作为残障 关怀）。

虽然我会外出购物并看望我的孩子，但我仍然对访客和外出就餐持犹豫态 度（尽管我已接种疫苗）。随着学校的准备工作加强, 我们面临新毒株 带来的进一步不确定性。这将对COVID-19的恐惧重新置于中心。于我而 言, 最大的困难之一是无法作规划。今年11月, 我受邀在亚利桑那州菲尼 克斯市举办的美国老年学学会（GSA）会议展示收录的多篇摘要, 但我一 直对出行安全和面对面互动感到迟疑。近期, GSA宣布, 该会议将转为网 络模式。我意识到, 不可预测性是老年现实的一部分。这可能是解释之前 提到的“老年人并不比年轻人更多地担忧大流行”的一个原因。

与此同时，大流行的不确定性仍然索绕在我的生活中。上周，UPS司机送 来了之前我在费城旅行时寄回的箱子。当我发现站在门口的司机没有佩戴 口罩时, 我迅速回到了走廊里, 并感受到了接种疫苗前所熟悉的恐惧。

\section{聚焦于COVID-19和老年人的研究方法限制}

过去一年里有许多研究分析了COVID-19对老年人带来的独特挑战。本期 JEP增添了聚焦于国内和国际的文章，以期更好地理解这一重要主题。在 评价老龄化和COVID-19的研究质量时，我们必须承认当前文献在为 “理 解COVID-19大流行对老年人、其家庭、护理人员以及医疗提供商的生活 造成的影响” 提供一个涵盖面广且有深度的解释时存在的限制。问题在 于, 研究者和其研究对象所生活和工作的情境存在诸多限制。鉴于正在进 行的大流行威胁, 我们还无法将传统方法适用于有关大流行影响的研究。

与基于代表性样本并通过调查或面对面访谈收集数据的传统社会科学研究 所不同的是，与COVID-19相关的大多数当前研究并不具备这些标准。大 
流行开始后, 研究者缺乏以往用于申请同行评审基金的机会。大多数研究 者也没有用于撰写优质课题所需的设施和支持。封城期间, 老年人无法通 过面对面形式进行访谈。因此, 研究者很难通过居家办公的方式收集数 据。关于老年人的数据基本通过网络或手机通话的形式收集。

大多数关于COVID大流行的研究数据收集于 2020 年上半年。如上所述, 为 快速收集相关数据, 学者依靠基于网络的调查（Barber \& Kim, 2021）。这 类调查过多地包含了那些教育程度良好的、有电脑和网络获取机会以及懂 得数字技术的调查对象。少数群体在这类样本中的代表性不足。此外, 生 活在长期护理机构的老年人（他们是大流行的首批重要受害者）几乎没有 被包括在COVID-19研究范围内。这些老年人面临严格的生活限制。他们 的家人被禁止拜访, 因此无法对有关该高度脆弱的受害群体的生活经历提 供第一手的个人陈述 。那些在护理机构中感染COVID-19的老年人面临高 死亡率。仅 210 万人口（占美国总人口的 $0.62 \%$ ）居住在护理院或依靠辅助 生活设施生活。不过, 截至2020年5月22日, 该群体中因感染COVID-19去 世的人数占COVID-19总死亡人数的 $42 \%$ （Girvan, 2020）。

在总结本期JEP收录的文章之前, 我想提供一些从与老年人和COVID-19相 关的文献中得出的见解。Heid 等人（2021）探究了大流行最初几个月里老 年人经历的挑战。其样本对象 $(\mathrm{N}=1272)$ 面临的最频繁的问题有关于大流 行期间的社交互动限制。Whitehead 和Torossian（2021）的混合方法研究

$(\mathrm{N}=825)$ 得出了相同的研究发现, 并指出, $42 \%$ 的老年受访者报告了受 限的社交互动, $30.9 \%$ 的受访者报告了活动限制。他们还发现, 最频繁的 压力源是活动限制和孤独。

关于COVID-19和老龄化的文献还聚焦于护理提供（caregiving）。大流行 期间老年人护理提供的复杂需求已导致护理人员出现焦虑、抑郁和其他精 神健康问题（Beach et al., 2021）。多名护理人员的存在经常会导致家庭冲 突 (Xu, Liu, \& Beach, 2021)。至于COVID-19的政策意义, 最重要的经验 之一包括年龄歧视情况的增加（Ehni \& Wahl, 2020）。COVID-19对老年 患者的健康和存活所产生的负面影响强调了老年生活的脆弱性, 并已导致 贬低老年人的年龄主义。鉴于老年人面临与COVID-19相关的负面结果风 险, 他们并不总是干预措施的重点对象, 并且在一些环境下, 他们不被视 为值得被拯救（Ehni \&Wahl, 2020）。通过进一步反思普遍的年龄主义, 美 国已正式采纳了呼吸机分配指南, 该指南指出： “在有限情况下, 年龄可 能被视为最终决策标准”（Zucker, Adler, \& Berens, 2015）。

与关于 “COVID大流行期间年龄主义情况增加所产生的消极影响” 的论 点不同的是, 一些证据表明: 老年人从基于联邦及各州的计划和津贴中获 益。Young等人 (2020) 提供了一份旨在响应COVID-19的新政策清单, 这 些政策能提升老年人医疗和生活质量。一些计划是短期的, 但却有可能延 长, 如果其能提供需要长期执行的证据。 
与COVID-19相关的本期JEP内容

本期JEP收录的大部分文章源于我们的征集文稿。不过，我们也收录了两 篇由Gullet博士、Nathan Stall博士及其同事所撰写的特约文章，这两篇文章 分别提供了关于美国和加拿大卫生提供商对大流行的重要看法。我们还收 录了由Ivan博士和Cutler博士撰写的关于罗马尼亚的跨国家视角文章。我们 的文章反映了跨学科视角, 并使用了包括医学、法律、营养学、社会学以 及历史学方法。

1. 《为老年人和集体居住者创造公平：地方公共卫生新冠肺炎响应第一 年得出的经验》由Heidi Gullett（医学博士兼公共卫生学硕士）撰写。文 章以医学和公共卫生为重点, 带领读者体验她作为俄亥俄州卫生委员会

( $\mathrm{CCBH}$ ) 响应团队的应急指挥员 (负责凯霍加县) 的第一手经验。Gullet详细描述了成功的部分, 以及她与多学科团队在这场大流行中获得的经 验。她尤其聚焦于大流行对脆弱人口（例如老年人、残障人士、集体居住 者、少数族裔、以及面临社会经济劣势的个体）产生的影响, 并描述了响 应团队如何尝试缓解COVID-19在这些群体间的爆发。一些举措包括：为 那些没有内科医生的人士提供内科医生热线、为边缘化群体提供检测、支 持系统和接种疫苗，以及在社区内建立信任。最后，Gullet提供了政策建 议, 聚焦于强化公共卫生基础设施, 以期预防未来卫生危机和/或为未来卫 生危机提供经验。

2. 《2019冠状病毒病和安大略省的长期护理院》由医学博士Nathan Stall 和合著者共同撰写。文章广泛分析了对加拿大安大略省长期护理设施中 COVID-19高感染率作贡献的风险因素。的确, 截至2021年7月, 安大略省 $43 \%$ 的COVID-19死亡人数是长期护理院（LTC，长期护理）的居民。分析 显示，LTC院COVID-19爆发风险与以下因素强烈相关：周边社区的感染 率、LTC院的营利状态、以及群体聚集。作者还分析了公共卫生干预措施 是否会对风险缓解一事产生任何影响, 并就在今后可能有效的其他措施 提出建议。这些措施包括：改善员工工作环境、限制员工在 14 天内仅在一 所LTC机构中工作、进一步减少群体聚集、检测优先化、保证员工的带薪 病假、提升感染预防措施、提升疫苗接受度策略、以及继续保持对关于 COVID-19和LTC院数据的快速收集和获取。

3. 《2019冠状病毒病大流行期间老年人的自我评价、宗教应对和心理健 康的种族差异》的作者是Timothy Goler博士、Tirth Bhatta博士、Nirmala Lekhak 博士以及Neema Langa（文学硕士）。文章将关注点从缓解措施转 向关于影响老年人精神健康的应对资源和策略的调查。通过使用一项关于 压力和应对机制的框架，作者分析了COVID-19大流行期间老年人健康的 种族差异。他们的网络调查 $(\mathrm{N}=1764)$ 具体审视了宗教应对、主观宗教 性、情感支持、以及对大流行的自我评价如何影响焦虑症和抑郁症的种族 差异。他们的研究发现显示, 黑人比白人展示了更多关于大流行的关切, 但前者的抑郁症状和焦虑程度却更轻。进一步分析表明，主观宗教性、宗 教应对和情感支持似乎能缓解黑人的压力。研究暗示，黑人和白人所获得 
的情感支持都以单独的方式影响其心理健康。

4. 《罗马尼亚的老年人和数字鸿沟：对 2019 冠状病毒病大流行产生的意 义》一文由罗马尼亚传播学学者Loredana Ivan博士和一名定居美国的社会 学家Stephen J. Cutler博士共同撰写。他们探究了数字鸿沟对老年人产生的 作用以及其对罗马尼亚COVID-19大流行产生的意义。鉴于大流行期间许 多线下活动转为线上平台，那些没有互联网获取机会或不懂得技术操作 的用户面临脆弱风险。对数字鸿沟作贡献的因素包括电脑和互联网的成 本。在东欧，许多年轻人离家去国外工作，他们的年迈亲人留在村里，没 有和子女联系的工具。这些老年人被鼓励学习技术但却没有资源购买所 需设备。尽管该研究所用的数据收集于大流行之前, 但作者就与大流行相 关的、老年人的互联网使用提出了重要观点。那些有获取机会和技能的 老年人很有可能发现学习新数字技能的机会, 而其他用户则可能面临社会 排斥。后者在生病时仍然依靠打电话给朋友和家人，以及与他人在线下见 面。

5. 《老年员工因 2019 冠状病毒病适应措施而面临的差别对待：年龄主义和 年龄歧视的潜在问题》由心理学家Lisa Hollis-Sawyer博士撰写。文章聚焦 于大流行期间老年员工面临的挑战。作者指出，COVID-19大流行转变了 美国员工的（工作）环境。许多员工被解雇或不得不适应网络平台。大流 行发生之前，出现在工作场所的歧视和年龄主义已经是老年员工面对的 大问题。通过研究2020年就业趋势, Hollis-Sawyer分析了老年员工面对的 与大流行相关的压力。她的文章显示了对老年员工产生的消极影响以及 自然损耗效应（wear and tear effects），包括非自愿提前退休、发生在工 作场所的、基于技术使用刻板印象的歧视、感知健康脆弱性、以及代际间 矛盾。Hollis-Sawyer的结论为 “雇主通过何种方式创造老年友好型工作环 境”一事提供了建议。建议的策略包括：1）减少年龄歧视，2）培训员工 避免刻板印象，3）逐一看待员工，4）培训员工有关老龄化的问题。

6. 《伤寒玛丽的回归? 疗养院的移民员工》一文由法律教授Shefali Milczarek-Desai（职业法律博士兼文学硕士）和Tara Sklar（职业法律博士兼公共 卫生学硕士）共同撰写。文章聚焦于疗养院的员工问题。长期护理机构中 成千上万的COVID-19病例能溯源到照顾居民的护理助手。作者通过审视 美国史上流行病事件与低薪移民员工之间的关系，探究了COVID高传染率 的潜在起因。为此他们呈现了 “伤寒玛丽” 的故事, 作为一名贫穷的爱尔 兰移民员工，她在100年前因传播伤寒而被称为美国最危险的妇女。作者 展示了护理助手的恶劣工作环境，后者促使她们在多家疗养院工作并且没 有能力请带薪病假。护理助手工作的危险性质经常导致她们在损失收入和 为病毒传播作贡献之间做选择。作者的结论就低薪移民员工带薪病假批准 执行一事提出了具体的政策建议。

7. 《为灾害而设的舞台: 营利性疗养院、联邦法和2019冠状病毒病》的 作者是法律历史学家David Papke（兼职业法律博士）。文章同样聚焦于 
COVID-19在疗养院居民中的高感染率和死亡情况。为探究此灾害在这些 情境中发生的原因，他采用有关宏观因素的方法（upstream approach）， 为营利性疗养院的兴起提供历史信息。Papke主张，营利性模式并未给居民 提供安全的、尽责的护理。营利性疗养院经常通过节省感染控制措施和员 工成本的方式将利益最大化。Papke指出, 联邦规制经常对不合规的疗养 院不采取任何惩罚, 并且推动感染控制的一系列规制在大流行发生之前反 而减少了。文章涃熟地描述了这些疗养院如何将利润摆在比病人护理更高 的位置，尤其是在大流行期间（例如接收COVID检测结果呈阳性的患者） 。Papke的结论提出了监管政策建议。

8. 《用于在大流行中支持社区老年人营养的政策基础：从2019冠状病毒病 得出的经验

》一文由研究营养学和法学的学者撰写, 他们分别为Meredith Whitmire ( 职业法律博士）、Mary Beth Arensberg（博士兼注册营养师）、Alexandra Ashbrook（职业法律博士兼法学硕士）、以及Robert Blancato（公共管理 硕士）。文章强调了营养在支持一个强健的免疫系统中发挥的重要作用。 不幸的是，许多老年人营养不良或面临粮食不安全，这让他们面临加大的 慢性病风险。营养不良的老年人面临感染COVID-19和遭受其并发症的风 险。尽管营养不良和粮食不安全是熟知的老年问题，但在护理访问中却经 常不篮查这两项内容。这篇文章概述了基于社区的、由联邦出资的老年营 养服务, 这对大流行期间的老年人而言变得尤为重要。文章最后给出了政 策建议，以确保老年人能获取充足的营养，甚至在大流行后期。这些建议 聚焦于如何增加社区服务资金，这已被证明能帮助应对该需求。

结语

本期JEP以重要的方式聚焦于正在进行的COVID -19大流行。每篇文章都 对老年人和大流行提供独特的创新视角。不过，鉴于该威胁快速变化的 性质, 以及作者所呈现的视角有限, 我们仅能部分概述大流行的影响以及 老年人的未来需求。此时, 清晰的是, 大流行将对老年人的身体健康和精 神健康产生长期的消极效果（Morrow-Howell，2020）。特别地, 社会隔离 和孤独证明为老年人带来了重大的消极精神健康问题 (Van Tilburg et al., 2020；Wu，2020）。不过，正式和非正式计划都被证明有助于抵消社会隔离 （Kahlon et al., 2021）。老年人也取得了一些积极发展，包括技术技能的提 高、自我护理程度提升、以及主动减少社会隔离（Morrow-Howell, 2020。

2021年初秋, 在我们出版之际, 我们正学着与一个认识共存, 这个认识则 是，我们正处于一场新的病毒激增形势中，具有高传染性的德尔塔变异毒 株对绝大多数未接种疫苗的人产生影响, 也同时对已接种疫苗的人产生突 破性感染。尽管FDA已批准了疫苗，但仍然有部分人对接种疫苗一事保持 迟疑态度。那些在大流行早期尤其受到影响的老年人有幸在美国拥有相对 高的疫苗接种率，并且他们如果遭遇突破性感染，则会免受大多数严重结 
果的影响（Teran et al., 2021）。不过，日益明显的是，大流行还未离去。 此外，我们必须承认COVID是一个全球问题，而非地方问题。我们必须小 心谨慎并且同时对 “这场战役的下一章将带来一些新的 “突破” ”一事保 持积极态度。决策者面临许多挑战，而创新性想法能为其提供巨大价值。

\section{References}

Abrams, H. R., Loomer, L., Gandhi, A., \& Grabowski, D. C. (2020). Characteristics of US nursing homes with COVID-19 cases. Journal of the American Geriatrics Society, 68(8), 1653-1656.

Allcott, H., Boxell, L., Conway, J., Gentzkow, M., Thaler, M., \& Yang, D. (2020). Polarization and public health: Partisan differences in social distancing during the coronavirus pandemic. Journal of Public Economics, 191, 104254.

Barber, S. J., \& Kim, H. (2021). COVID-19 worries and behavior changes in older and younger men and women. The Journals of Gerontology: Series B, 76(2), e17-e23.

Beach, S. R., Schulz, R., Donovan, H., \& Rosland, A. M. (2021). Family caregiving during the COVID-19 Pandemic. The Gerontologist, 61(5), 650-660.

Ehni, H. J., \& Wahl, H. W. (2020). Six propositions against ageism in the COVID-19 pandemic. Journal of Aging \& Social Policy, 32(4-5), 515-525.

Girvan, G. (2020). Nursing homes \& assisted living facilities account for 38\% of COVID-19 deaths. Retrieved from https://freopp.org/the-covid-19-nurs ing-home-crisis-by-the-numbers-3a47433c3f70

Han, Q., Zheng, B., Cristea, M., Agostini, M., Belanger, J. J., Gützkow, B., ... \& Leander, P. (2020). Trust in government and its associations with health behaviour and prosocial behaviour during the COVID-19 pandemic. PsyArXiv Preprints.

Heid, A. R., Cartwright, F., Wilson-Genderson, M., \& Pruchno, R. (2021). Challenges experienced by older people during the initial months of the COVID-19 pandemic. The Gerontologist, 61(1), 48-58.

Kahlon, M. K., Aksan, N., Aubrey, R., Clark, N., Cowley-Morillo, M., Jacobs, E. A., ... \& Tomlinson, S. (2021). Effect of layperson-delivered, empathy-focused program of telephone calls on loneliness, depression, and anxiety among adults during the COVID-19 pandemic: A randomized clinical trial. JAMA Psychiatry, 78(6), 616-622. 
Latkin, C. A., Dayton, L., Strickland, J. C., Colon, B., Rimal, R., \& Boodram, B. (2020). An assessment of the rapid decline of trust in US sources of public information about COVID-19. Journal of Health Communication, 25(10), 764-773.

Morrow-Howell, N., Galucia, N., \& Swinford, E. (2020). Recovering from the COVID-19 pandemic: A focus on older adults. Journal of Aging \& Social Policy, 32(4-5), 526-535.

Sallam, M. (2021). COVID-19 vaccine hesitancy worldwide: a concise systematic review of vaccine acceptance rates. Vaccines, 9(160), 1-14.

Sheik-Ali, S., Sheik-Ali, S., \& Sheik-Ali, A. (2021). Hearing impairment and introduction of mandatory face masks. Editorial. Ear, Nose, \& Throat Journal, $1-2$.

Vahia, I. V., Jeste, D. V., \& Reynolds, C. F. (2020). Older adults and the mental health effects of COVID-19. JAMA, 324(22), 2253-2254.

Teran, R. A., Walblay, K. A., Shane, E. L., Xydis, S., Gretsch, S., Gagner, A., ... \& Black, S. R. (2021). Postvaccination SARS-CoV-2 infections among skilled nursing facility residents and staff members-Chicago, Illinois, December 2020-March 2021. American Journal of Transplantation, 21(6), 2290-2297.

Van Tilburg, T. G., Steinmetz, S., Stolte, E., van der Roest, H., \& de Vries, D. H. (2020). Loneliness and mental health during the COVID-19 pandemic: A study among Dutch older adults. The Journals of Gerontology: Series B, 76(7), e249-e255.

Whitehead, B. R., \& Torossian, E. (2021). Older adults' experience of the COVID-19 pandemic: A mixed-methods analysis of stresses and joys. The Gerontologist, 61(1), 36-47.

$\mathrm{Wu}, \mathrm{B} .(2020)$. Social isolation and loneliness among older adults in the context of COVID-19: A global challenge. Global health research and policy, 5(1), 1-3.

Xu, J., Liu, P. J., \& Beach, S. (2021). Multiple caregivers, many minds: Family discord and caregiver outcomes. The Gerontologist, 61(5), 661-669.

Young, H. M., Quinn, W., Brassard, A., Gualtieri, C., \& Reinhard, S. (2020). COVID-19 pandemic spurs policy changes benefiting older adults. Journal of Gerontological Nursing, 46(6), 19-23.

Zucker, H., Adler, K., Berens, D., Bleich, R. J. D., Brynner, R., \& Butler, K. A. (2015). Ventilator allocation guidelines. Albany: New York State Department of Health Task Force on Life and the Law. 